November 2014

\title{
The Left-To-Die Boat: Review 2
}

Peter Mares

Swinburne University, Inside Story

Follow this and additional works at: http://ro.uow.edu.au/rdr

Part of the African Languages and Societies Commons, Audio Arts and Acoustics Commons, Digital Humanities Commons, Human Rights Law Commons, Law of the Sea Commons, and the $\underline{\text { Radio Commons }}$

\section{Recommended Citation}

Mares, Peter, The Left-To-Die Boat: Review 2, RadioDoc Review, 1(2), 2014. doi:10.14453/

rdr.v1i2.7

Research Online is the open access institutional repository for the University of Wollongong. For further information contact the UOW Library: research-pubs@uow.edu.au 


\title{
The Left-To-Die Boat: Review 2
}

\begin{abstract}
In March 2011 an inflatable boat carrying 72 asylum seekers from sub-Saharan Africa set out from the coast of Libya hoping to reach the Italian island of Lampedusa. As one Italian official commented, sailing from Libya towards Italy should have been 'a bit like doing a slalom between military ships'. Yet as, out of fuel, supplies of food and water dwindled to nothing and the people on board began to get sick and die, the boat continued to drift and no help came. Eventually it floated all the way back to the Libyan coast. Of the 50 men, 20 women and two babies who set out to sea, only eleven remained alive.
\end{abstract}

Sharon Davis and Geoff Parish reconstruct this tragedy through interviews with five young men who survived the trip. Their first-person accounts of the journey are augmented by interviews with sympathetic Dutch politician Tineke, Rome-based Eritrean Priest Father Mussie Zerai, who was contacted by the passengers by satellite phobe, human rights investigator Lorenzo Pezzani, who forensically reconstructed the boat's movements, and dour NATO spokesperson Oana Lungescu. One survivor (Abu Kurke) speaks in halting English; for the others the vernacular is faded under voice-overs. It is raw, simple narrative, expertly selected and edited to move the story seamlessly forward while also allowing listeners time to form mental images of the boat and its passengers and to absorb the emotional impact of what they are hearing. The survivors' individual accounts overlap and repeat to poetic effect, underscoring the veracity of their testimony. The survivors' tale floats on a bed of sound - the splash of waves; the hum of a boat motor; restrained, ominous music (with cello predominating), and the occasionally distant chime from an old clock tower marking the relentless passing of time and its deadly impact on the voyage.

The radio makers' approach is dignified, restrained and powerful. Just as the clean lines of minimalist architecture can rely on sophisticated engineering, so the apparent simplicity of a chronological account conceals the artistry, deep thought and sheer hard work of radio production. A strong undercurrent of anger flows through the documentary, and we are given strong encouragement to doubt that NATO has been fully truthful in its response to the tragedy.

The Left-To-Die Boat won a United Nations Association of Australia Media Peace Prize and was shortlisted for a Sony Academy award (UK), the New South Wales Premier's Literary Awards and the Australian Human Rights Awards.

\section{Keywords}

asylum seekers, NATO, refugees, documentary 


\section{The Left-to-Die Boat}

Producers: Sharon Davis \& Geoff Parish, ABC RN 360 Documentaries (Australia 2012), technical production Steven Tilley. 52mins

\section{Reviewer: Peter Mares}

In March 2011 an inflatable boat carrying 72 asylum seekers from subSaharan Africa set out from the coast of Libya hoping to reach the Italian island of Lampedusa. This is not an unusual occurrence - in fact in the years since then such journeys have become increasingly common - yet this boat journey was extraordinary by any account. Elements of the survivors' tale are nevertheless sadly familiar to anyone who has listened attentively to the testimony of refugees.

The condensed version of this particular story is that within two days, and perhaps about half way to its destination, the asylum seekers' overloaded boat ran out of fuel, but not before its departure from Libya had been documented by a French surveillance plane. As the boat drifted for a further 13 days, supplies of food and water dwindled to nothing and the people on board began to get sick and die. During this time a military helicopter flew over the boat twice, dropping emergency supplies of biscuits and water on its second pass; a large naval vessel came so close that passengers on the boat could see sailors taking pictures of them from the deck; contact was made with at least two fishing boats, and once every four hours for ten days the Italian Maritime Rescue Coordination Centre (MRCC) broadcast an alert giving the boat's approximate location and calling on any nearby vessels to provide assistance. All this at a time when additional NATO vessels were deployed in the Mediterranean as part of Operation Unified Protector, using sea and air power to 'protect civilians from the threat of attack' by enforcing an arms embargo and a no-fly zone against Libya. ${ }^{1}$ As one Italian official commented, sailing from Libya towards Italy should have been 'a bit like doing a slalom between military ships'. ${ }^{2}$ Yet the boat

\footnotetext{
${ }^{1}$ NATO newsroom media statement, 31 October 2011 http://www.nato.int/cps/en/natolive/71679.htm

'Quoted in, Strik, Tineke "Lives lost in the Mediterranean Sea: who is responsible?" Report for the Committee on Migration, Refugees and Displaced Persons, Council of Europe, March 2012 
continued to drift and no help came. Eventually it floated all the way back to the Libyan coast. Of the 50 men, 20 women and two babies who set out to sea, only eleven remained alive. Two of them subsequently died - one immediately after making landfall, the other after Libyan authorities detained the returning asylum seekers in prison.

Sharon Davis and Geoff Parish reconstruct this tragedy through interviews with five young men who survived the trip - Mohamad Ibrahim, Elias Kadi, and Kebede Dadhi who have been resettled in Australia as refugees - and Ghirma Halefom and Abu Kurke Kebato whose applications for protection in Europe were still pending at the time the program was made. Their first-person accounts of the journey are augmented by interviews with sympathetic Dutch politician Tineke Strik who has prepared a detailed report into the Left-to-Die Boat; ${ }^{3}$ Rome-based Eritrean Priest Father Mussie Zerai, who was contacted by the passengers by satellite phone and who alerted the MRCC to their plight within 24 hours of the boat leaving Libya; human rights investigator Lorenzo Pezzani, who forensically reconstructed the boat's movements and dour NATO spokesperson Oana Lungescu, who deflects most of the questions put to her. (In a perhaps unwitting indication of where the producers' sympathies lie, Lungescu is not named in the credits on the 360 Documentary website, although additional audio is provided for those who wish to hear the original NATO interview in full. ${ }^{4}$ )

The approach of Davis and Parish to this story is straightforward. We are essentially given a chronological account of the journey, beginning with the young men's reasons for fleeing Libya. At the time, sub-Saharan Africans stood accused of being employed as mercenaries by Libyan dictator Muammar Gaddafi in his conflict with anti-government rebels as a result, dark-skinned migrants from countries like Ethiopia and Eritrea were at constant risk of reprisal attacks.

\section{Audio Excerpt 1: Reasons for escaping Libya}

Libyan soldiers are involved in the people-smuggling operation and force the asylum seekers to ditch personal baggage, including precious supplies of food and water, in order to crowd more passengers on the

\footnotetext{
${ }^{3}$ Ibid.

${ }^{4}$ http://www.abc.net.au/radionational/programs/360/left-to-die-nato-interview/4220750
} 
boat. Still, the journey starts out optimistically enough on a calm sea. Before long bad weather hits and the mood changes. The 'captain' does not know how to work the GPS tracking equipment to give the MRCC an accurate account of their location, the batteries go flat on the satellite phone, a young man falls overboard; another drowns trying to save him.

One survivor (Abu Kurke) speaks in halting English; for the others the vernacular is faded under voice-overs. It is raw, simple narrative, expertly selected and edited to move the story seamlessly forward while also allowing listeners time to form mental images of the boat and its passengers and to absorb the emotional impact of what they are hearing. The survivors' individual accounts overlap and repeat to poetic effect, underscoring the veracity of their testimony. The survivors' tale floats on a bed of sound - the splash of waves; the hum of a boat motor; restrained, ominous music (with cello predominating), and the occasionally distant chime from an old clock tower marking the relentless passing of time and its deadly impact on the voyage.

The witness accounts of the boat journey are put in context with media excerpts explaining the war in Libya, the resulting refugee flows and Operation Unified Protector. There are also recreations of the MRCC distress calls. This documentary material is reinforced with external comment from the politician, the priest, the human rights activist and the defensive NATO official. There is no lapping of waves when we hear from these outside observers. We are moved from the realm of distressing personal memories, to the realm of distressing political facts.

Put like this, The Left-to-Die Boat might sound like rather conventional reportorial journalism and in some ways it is. On occasion the techniques are a little too obvious - mention is made of a surveillance plane and then we hear the sound of a plane flying overhead, ditto when we hear about the helicopter. On the whole though, the radio craft at work here is highly skilled and mostly invisible. Just as the clean lines of minimalist architecture can rely on sophisticated engineering, so the apparent simplicity of a chronological account conceals the artistry, deep thought and sheer hard work of radio production. The story is constructed almost entirely from the raw material of the interviews, with very limited authorial intervention in the form of scripting and narration. Essential information like the name of a speaker is supplied when necessary, but there is no spoon-feeding of the audience nor heavy-handed editorialising - we are left to work out the nuances and 
complexities for ourselves. This is not to say that there is no authorial perspective. A strong undercurrent of anger flows through the documentary, and we are given strong encouragement to doubt that NATO has been fully truthful in its response to the tragedy.

Nor does extraordinary material require much embellishment. A more tabloid approach to this disaster might have frontloaded some of the terrible accounts of death on the boat to the front of the documentary with the aim of grabbing the listeners' attention. This might have numbed and distanced us from the start, but Davis and Parish draw us in by allowing the story to unfold more slowly. It is thirty minutes in before we hear the survivors' accounts of watching people die.

\section{Audio Excerpt 2: Death on the Boat}

Davis and Parish allow questions to rise in the mind of the listener, but do not rush to answer them. When I listened to the accounts of people dying on the boat, I could not help wondering what their friends and relatives did with the bodies. Did they throw them overboard or keep them by their side. Did they argue with each other about what to do? The documentary eventually provides a partial answer to such questions, but not in a way that is invasive or explicit. The radio makers' approach is dignified, restrained and powerful. By allowing such questions to arise in my mind but not immediately answering them, they have nudged me to think myself onto the boat, forced me to consider my reactions in similar circumstances.

\section{Audio Excerpt 3: Bodies}

The story of The Left to Die Boat is exceptional and extraordinary 'amazing' as survivor Abu Kurke puts it. As an Australian listening to this documentary, however, I was cognisant of the universality of the survivors' experiences and the many parallels with the journeys of asylum seekers sailing to Australia from Indonesia. The role of police and security forces in facilitating the smuggling operation, the asylum seekers' shock when they see how small and flimsy and overloaded the boat is, compared to what the smugglers led them to believe when they parted with thousands of dollars; the initial optimism as the vessel departs, the growing trepidation, fear, sea-sickness and desperate resort to prayer as the weather deteriorates and the boat begins to fall apart. 
There are other similarities too, with the failure to render assistance. Survivors of the SIEV $X^{5}$ disaster in October 2001 reported that large vessels with floodlights approached them as they clung to wreckage in the Indian Ocean, and then departed again without rescuing anyone. On 21 June 2012, just two months before The Left-to-Die Boat was first broadcast, a boat known as Kaniva sank en route to Christmas Island with the suspected loss of 102 lives. (Exact numbers are uncertain because many of the bodies were never recovered.) At the coronial inquest it was revealed that 'there had been multiple satellite telephone calls' to the Australian Maritime Safety Authority Rescue Coordination Centre from the Kaniva 'from as early as 7.52am on 19 June 2012 ... in which concerns were raised as to the safety of the vessel and help was sought', yet mayday relays to shipping in the area were not initiated until two days later. That was after a Dash 8 Border Protection aircraft had sighted the vessel keel-up, its remaining passengers either perched precariously on the hull or struggling to survive in the water. ${ }^{6}$

As West Australian state coroner Alistair Hope commented:

Clearly if a search and rescue response had been initiated at that early time or at any later time significantly earlier than the search and rescue response was in fact initiated, lives could have been saved and if the response had been early enough, all of the deaths could have been avoided.

Over the twelve months from October 2013, and in response to the Lampedusa boat tragedy in which 366 people are believed to have drowned $^{7}$, the Italian navy has reportedly intercepted 150,000 people and brought them safely to shore under an operation called Mare Nostrum (Our Sea). Countless lives have no doubt been saved in the process. But in late 2014 boat arrivals to Europe are running at 400 per day, three times the level of one year earlier, and other European nations have become impatient with Italy's humanitarian approach,

\footnotetext{
${ }^{5}$ SIEV is an Australian government acronym that stands for Suspected Illegal Entry Vessel. Each asylum boat was given a number on arrival - thus becoming SIEV 34 or SIEV 58. As this boat never arrived it was called SIEV X, with the $X$ standing for its unknown number.

${ }^{6}$ WA State Coroner, Record of Investigation into Death, Ref No: 23/13 'Inquest into the death of 17 persons off Christmas Island on 21 June 2012", 31 July 2013 http://www.coronerscourt.wa.gov.au/ files/operation calder finding.pdf

7 Zed Nelson “Lampedusa boat tragedy: a survivor's story' The Guardian , 22 March 2014 http://www.theguardian.com/world/2014/mar/22/lampedusa-boat-tragedy-migrants-africa
} 
arguing that rescuing lives at sea acts as a 'pull factor' encouraging even more asylum seekers to risk the crossing. ${ }^{8}$

At the time of writing this review, Italy's Mare Nostrum program was being phased out and replaced by a European Union initiative called Operation Triton. Unlike Australia's naval intervention in the ocean between Christmas Island and Indonesia, it will not attempt to turn back boats, but nor will it take the more pro-active Italian approach to maritime search and rescue operations.

The ugly calculation is that downgrading the safety of life at sea will make the perils of the Mediterranean crossing much more apparent to asylum seekers, and deter them from starting out. It may of course be true that Italy's humane response to asylum seekers did encourage more people to set out from Libya in boats; it does not necessarily follow that a harsher approach will necessarily stop them from fleeing increasingly desperate situations in Libya, Iraq or Syria.

British Foreign Office minister Lady Anelay put it plainly: 'We do not support planned search and rescue operations in the Mediterranean.' Commenting in the London Telegraph, Dan Hodges summarised the message even more bluntly:

We're going to take those refugees, and we're going to drown them. ... Our Government's argument is - and this is literally the logic of Lady Anelay's statement - "We understand that by withdrawing this rescue cover we will be leaving innocent children, women and men to drown who we would otherwise have saved. But eventually word will get around the war-torn communities of Syria and Libya and the other unstable nations of the region that we are indeed leaving innocent children, women and men to drown. And when it does, they will think twice about making the journey. And so eventually, over time, more lives will be saved."

\footnotetext{
${ }^{8}$ Nick Miller "The refugee crisis in the Mediterranean is a story of death and desperation" Sydney Morning Herald, 31 October 2014 http://www.smh.com.au/world/the-refugee-crisis-in-themediterranean-is-a-story-of-death-and-desperation-20141031-11eu3y.html

${ }^{9}$ Dan Hodges "Drown an immigrant to save an immigrant" The Telegraph, 28 October 2014 http://www.telegraph.co.uk/news/politics/11192208/Drown-an-immigrant-to-save-an-immigrantwhy-is-the-Government-borrowing-policy-from-the-BNP.html
} 
The Australian government uses the same logic when it says it is attempting to protect some children (from getting on boats) by knowingly harming other children (in detention centres on Christmas Island and Nauru).

In such circumstances, what is a journalist or radio broadcaster to do? The facts no longer cut through and a lack of information is in any case not the problem. We know but we just don't care. Or as a newly installed Pope Francis put it in July 2013, when he visited Lampedusa to meet with African migrants and asylum seekers, 'We are no longer attentive to the world we inhabit. ${ }^{10}$ By listening and asking questions, carefully researching and retelling, Davis and Parish remain attentive and help us to remain attentive too.

AUDIO of The Left-To-Die Boat is HERE.

Declaration of interest: Having previously worked as a broadcaster with ABC Radio National, Peter Mares is a former colleague of producers Sharon Davis and Geoff Parish. He was based in a different department and a different city and left the ABC in December 2011.

\footnotetext{
${ }^{10}$ Quoted by Klaus Neumann in "Attentiveness and Indifference", Inside Story 22 July 2013, http://insidestory.org.au/attentiveness-and-indifference
} 
PETER MARES is contributing editor with the online journal Inside Story, adjunct fellow at the Institute for Social Research at Swinburne University and a moderator with the Cranlana Programme. Previously Peter worked for twenty-five years as a broadcaster with the ABC. Throughout his career he has combined journalism with public policy research, particularly on topics related to migration. He is the author of Borderline (UNSW Press 2001 \& 2002), an award-winning book analysing Australia's approach to refugees and asylum seekers. His most recent essay on refugee issues is 'Refuge without work' from Griffith Review, Edition 45. It is shortlisted for a 2014 award made by the Australian Human Rights Commission.

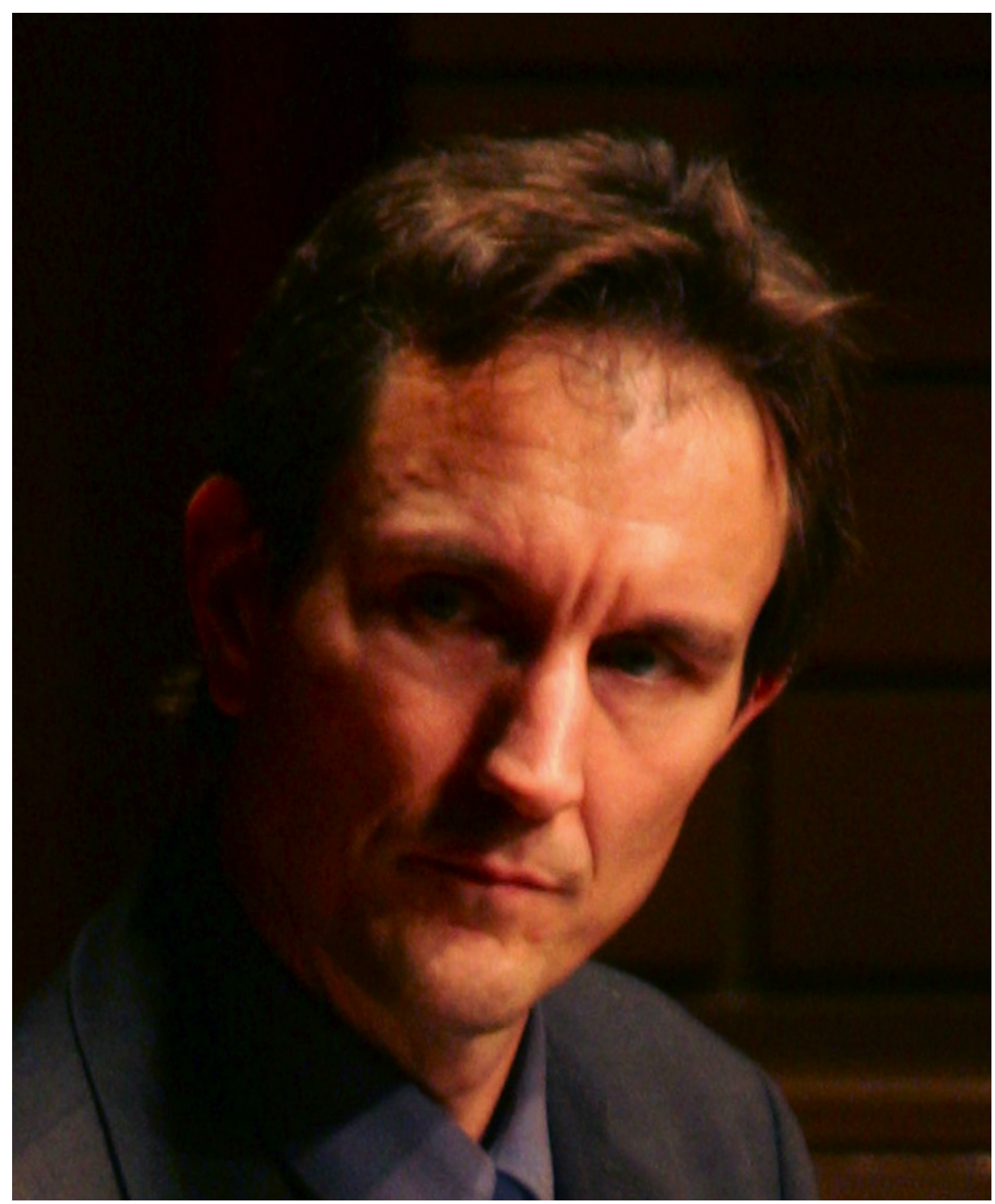

